\title{
The Current Situation of Teacher Education in Chinese Application-Oriented Universities and Improvement Strategies
}

\author{
Shijie Wang \\ Hefei Information Technology University \\ Montpellier University, France
}

\begin{abstract}
Teacher education is an important part of the construction of the teaching team, which plays a very valuable mediating role between teacher planning, qualification access, evaluation incentive and teacher quality. Teacher education in application-oriented universities is set to carry out planned and targeted training activities for teachers based on school development and goals of teaching team construction. In recent years, plenty of achievements have been made in application-oriented universities, but problems exist, too. Examples are as follows: a lack of specialized institutions for application-oriented teacher education; failure of cultivation modes in satisfying young teachers' development needs; failure to meet the diversified demand due to imbalance between training supply and demand fails to meet the need for diversification; not-targeted training content and difficult quality guarantee; unsound training management and assessment mechanism, dissatisfying training effect. For teacher education facing 2035 in application-oriented universities, we should set up a teacher's profession development center, pay attention to in-school training, and carry out the construction of qualified personnel in education at different levels.
\end{abstract}

Keywords: Application-oriented universities, Teacher education, Dilemma, Strategy.

\section{Current Research of Teacher Education in Application-oriented Universities}

The key driving force of university transformation lies in the transformation of teachers. The academia have reached several consensuses on how to promote university teachers from being academic-inclined to application-inclined. For example, Zhan Xianming(2010)[1], in his paper "Double-qualified Type Teacher Development Theory", summed up four training modes under the "double-qualified type", namely, college training mode, school-enterprise cooperation mode (enterprise grafting mode), school-based training mode and self-study mode. Chen Wei, Tian Guojie, et al. (2012)[2] also summarized the cultivation mode of "double-qualified-type" teachers into the above four, and recommended "school-enterprise cooperation" one to be the most effective mode to train "double-qualified-type" teachers. Zhang Wenjiao (2019)[3] also put forward in her dissertation that applied-tended teachers of undergraduate courses can be trained by three ways: school-based training, school-enterprise cooperation and self-study.

Fu Bajun (2017)[4] once published On the Endogenous Model of application-oriented universities' Teaching Staff Construction in Zhejiang Social Sciences, and analyzed two models of application-oriented universities' teaching staff construction: external introduction and internal formation according to sources of teachers. According to analysis, at present, development of application-oriented college teachers in China should mainly adopts school-based cultivation mode, instead of bringing in mature double-qualified-type teachers externally. The reasons are as follows: on the one hand, the development policy of colleges and universities led by discipline competition has not changed. The evaluation system focuses on the pursuit of metaphysical theory and pays attention to the production of academic achievements rather than the application of academic achievements. On the other hand, external environment in which the characteristics are developed is not yet mature. Application-oriented universities are restricted by the maximum proportion of external teachers employed by general undergraduate universities. Teachers of public universities are required to meet the basic academic and degree requirements stipulated by the government, and the current salary system of colleges and universities can not be compared with many enterprises in the market with good benefits. Therefore, it is difficult for application-oriented universities to attract mature double-qualified talents with up-to-standard academic qualifications, theoretical literacy and practical experience. In this case, the major approach to building qualified teaching staff in application-oriented universities is still to introduce and train those academic talents who graduated from colleges and universities, and to promote them to be applied teachers who combine theory with practice by combining various modes such as on-campus training, off-campus practice (school-enterprise cooperation) and self-generation.

\section{Practical Difficulties in Implementing Teacher Education in Application-oriented Universities}

Teacher education in application-oriented universities is set to carry out planned and targeted training activities for teachers based on school development and goals of teaching team construction. Although many achievements have been made in recent years, there are still some problems.

\subsection{A Lack of Specialized Institutions for Application-} oriented Teacher Education

At present, application-oriented universities' teacher education system is not perfect, which is mainly reflected in the lack of special training institutions and according plans. First of all, absent of specialized institutions for training 
applied-oriented teachers. For one thing, most of the new teachers recruited in application-oriented universities come from regular institutions of higher learning. Alternative teacher training completed by regular institutions of higher learning has an inherent closure. This makes the professional development of teachers in application-oriented universities difficult to meet the needs of the rapid development of society for the quantity, structure and quality of teachers in both breadth and depth, and becomes the "bottleneck" restricting the development of higher vocational education. For another, due to the lack of funds dedicated to teacher training, it is difficult to build a special authoritative training institution. Although some education and training enterprises, driven by interests, take part in education and training according to the situation, the level is mixed. Secondly, some application-oriented universities lack specialized organizations for teacher development, training plans and programs suitable for the characteristics of their schools and the long-term development of teachers' career, and systematic planning and management for the training work[5].

\subsection{Cultivation Modes can not Meet Young Teachers' Development Needs}

Most application-oriented universities are formed by one or several technical colleges. Before upgrading, emphasizing the cultivation of teachers' practical ability and building a "double-qualified type" teaching team is their major feature of team building. However, after upgrading, influenced by various factors, application-oriented universities pay more attention to the academic structure of teaching team, introducing a large number of young teachers with doctoral or master's degrees. Due to the requirements of knowledge structure, specialty and professional title of teachers in colleges and universities, transformation of technical personnel in most enterprises in China to college teachers is limited. Therefore, channels for training and introducing teachers in undergraduate colleges are relatively single, with about $75 \%$ of teachers from school to school, most of them coming from academic research universities. The advantage of young teachers is that they have a solid theoretical level and strong research ability, but lack engineering practice ability, so they can't effectively use theoretical knowledge in practice. Under the current conditions, connection between pre-job training and post-job training of young teachers is not smooth, and there is a situation of "heavy introduction, light training", being short of coordinated planning and improved mechanism.

\subsection{Imbalance Between Training Supply and Demand Leads to Unmet Diversified Needs}

Currently, training for most teachers still follows the traditional model, while the industry-education-research mode has not been fully and effectively combined and carried out. As far as the current organizational form of training activities is concerned, training by disciplines is a method adopted by most colleges and universities. However, most of the trainers come from their own schools or teachers engaged in theoretical teaching, meaning they cannot meet the specific practical needs of trainees. The majority of schools fail to pay due attention to teacher training with very few related training offered. Meanwhile the training arrangements often conflict with teachers' teaching time, making them easily miss the rare training opportunities[6,7]. Imbalance between supply and demand in teacher development training and the high-level one is also observed. Teachers are extremely frustrated about it[8].

\subsection{Training Content is not Targeted and Quality is Difficult to Guarantee}

First, the training is not prominent enough, and the form is single. At present, most teachers training only pursues quantity instead of quality, and only pays attention to professional training instead of overall quality improvement. In particular, the ability needed to reflect the development of the new era has not been highlighted, and there is a lack of training specifically for the newly set or optimized disciplines and specialties, especially for the training of emerging composite disciplines. Second, training content is out of touch with teaching practice, and skill training is hard to be matched. The training content is mostly about professional scientific research knowledge and ability, while training for practical skills are much fewer, reflecting a phenomenon of "neglecting practice and emphasizing theory". Third, trainers in practical skills are uneven in professional level, and the quality is difficult to guarantee.

\subsection{Training Management and Assessment Mechanism is Unsound, Making Training Effect Less Satisfying}

Some application-oriented colleges do not have a management and assessment mechanism, and training becomes a mere formality. For trainees, accept the training plan, participate the activities, write a training reflection and reimburse the expenses would be counted as finishing the training. But the effect is neglected. Such training not only affects the improvement of teachers' quality, but is also not conducive to mobilization of teachers' autonomy and enthusiasm in training. The training effect does not make the most of its due value, let alone playing a good radiation role. This is also a waste of such training opportunities.

\section{Teacher Education in Application-oriented Universities Facing 2035}

For education modernization facing 2035, teacher education in application-oriented universities should take the initiative to adapt to social changes and future education development trend, and actively overcome difficulties in reality. Teachers' professional ability development centers should be set up to strengthen in-school training, reasonably introduce and classify training, and gradually improve the level and ability of application-oriented college teachers.

\subsection{Set up Teachers' Profession Development Center}

In order to systematically build quality teaching staff in application-oriented universities, it is necessary to set up teachers profession development center, so as to provide policy support and funds for teachers' orientation and continuing education, and strengthen their in-service education, improve teachers' knowledge structure, attach importance to teachers' profession training, enhance training's effect, and eventually change the "overestimate use, 
underestimate culture", "heavy research, light teaching" phenomena. Each side should be equally developed. According to characteristics of teachers' different types and levels, this development center should carry out scientific and reasonable school-based training for teachers, expands the caliber and training channels of teachers' professional development, constructs an advanced development model for teachers growth and cultivation, and diversifies forms of teacher training. The center should also pay attention to the incentive mechanism, making it possible for teachers to ask for the training, rather than to be "asked"; it should improve and modernize training facilities, so as to create various favorable conditions for teachers' professional development, enhance their scientific research ability and physical and mental health.

Teachers' professional ability development center is responsible for teachers' in-service education. On the premise of ensuring the normal progress of teaching, scientific research and management, it arranges and organizes teachers to receive continuation education in an organized and planned way. Specific job responsibilities are based on disciplines' needs and specialty construction, combined with teachers' personal growth goals and their own abilities, so as to make a targeted teachers training plan and provide them with diversified development measures, including induction education, morality education, class learning, on-the-job degree study, overseas study, enterprise assignment practice, project practice, on-the-job training and other learning forms. At the same time, according to characteristics of running colleges and universities and the advantages of professional disciplines, the center will jointly promote the study and training of college teachers in the whole province, set up a number of pre-job centralized training points for teachers and training centers for professional backbone teachers in colleges and universities, and do a good job in leading young teachers' growth at different levels with emphasis.

\subsection{Strengthen in-school Training}

In-school training is an important channel to improve teachers' teaching, scientific research and practical ability in application-oriented universities, and it is also a training method with low cost and good effect. It is mainly carried out in schools with characteristics being long-term, regular and flexible. The emphasis lies in practice teaching activities[9]. The school may, according to real situation and professional needs of teachers, formulate a corresponding training plan, determine the training objectives and the list of teachers to participate in the training, and employ relevant experts to teach, so as to improve the teaching level of the existing teachers in school and help the school to develop. In order to improve the professional level of existing teachers, in-school training can be divided into three stages: pre-service employment, in-service adaptation and post-service improvement.

Pre-service training is the training of teachers before they start the job. Pre-service training should implement the training plans, improve the training methods, train young teachers theories about modern higher education and application-oriented talent training concept in batches, so as to help teachers better understand the school and get familiar with the rules and regulations of various departments. In this way, teachers are able to complete the role transformation as soon as possible, and adapt their teaching idea, knowledge structure and teaching ability to the application-oriented educational purpose of colleges and universities and the training requirements of senior application-oriented talents.

In-service adaption period is the key period for teachers to improve themselves. Teachers who lack professional knowledge, professional practical skills and quality to a certain extent are required to reconstruct their knowledge system through special training in this period. Del Gedman (2001) put forward that in-service teacher training should be implemented during the job, and regards this further education as a system, and formulates relevant documents to standardize the further education and training of teachers in community colleges[10]. According to on-campus training plans, the school conducts targeted training for teachers during the adaptation period. On the one hand, teachers can be familiar with the whole production process and cultivate their practical awareness by arranging teachers to visit and inspect enterprises and industries in a planned and organized way; cultivate teachers' practical ability through field simulation and practical operation. Germany has a special "masters school", which is set to train practical skills and instructors, and also trains a large number of outstanding talents for handicraft industry and industry. On the other hand, in order not to affect the teaching progress, schools also can organize concentration training in teachers' spare time, or hire outside experts to carry a symposium, so that teachers can understand the market and social demand for talents, thus adjusting training plans and changing teaching methods. This can better cultivate high-level application-oriented composite talents that meet the needs of regional economic development and technological upgrading.

Post-service improving period is a stable period for teachers. Training should be carries out according to real situation, so that teachers can apply theory into application. This include: pay attention to practice; highlight practice in training process and improve teachers' practical level; pay attention to practicals, keep training content consistent with the courses taught and personal needs, and grasp teachers' real needs in skills and knowledge; pay attention to planning, change the scattered training methods, and promote teachers training in a planned and reasonable way. Through various training activities in school, teachers are encouraged to engage in scientific research, strengthen practice, and actively develop courses.

\subsection{Reasonable Introduction and Classified Training}

Application-oriented universities include newly upgraded undergraduate colleges, independent colleges, and institutions transformed from general undergraduate colleges. Due to the original junior college background, many application-oriented universities are short of top-notch talents, and the academic echelon structure is unreasonable, showing a state of talents shortage. In some universities, the academic echelon has a high age group or a certain age group, forming an inverted triangle structure and leading to a scholastic gap. This seriously affects the normal metabolism and sustainable development ability of the academic echelon[11]. There are 
also some application-oriented universities that place too much emphasis on short-term effects when setting up academic echelons, blindly introduce talents in a certain discipline field, and fail to form a multi-disciplinary and complementary scientific research team. This is also not conducive to interdisciplinary development and learning from others, thus may encourage academic degradation with repeated introduction. Some others lack of planning in allocation of human resources, which leads to surplus of personnel in some disciplines and even the internal consumption of human resources. On the other side, the serious shortage or even blank of personnel in some disciplines has seriously affected the construction and development of overall disciplines, rendering unbalanced talents allocation in different disciplines. As such, it is highly necessary to implement reasonable introduction, classified training and gradient talent echelon construction.

First, rationally introduce high-level talents and focus on training disciplinary pacemakers. First of all, the introduction of high-level talents must be scientifically planned and demonstrated around the development goals and actual needs of the school. The introduction should start from demands, insist on choosing talents with both morality and ability, highlight candidates' capability, performances and contribution, and overcome the tendency of overestimating academic qualifications, professional titles and papers. For high-end talents who can play a key role in the development of schools and are urgently needed by schools, special channels should be opened up, special policies should be implemented, accurate introduction should be realized, and direct employment methods of talents' titles should be explored. Secondly, intensify the training of academic leaders and disciplinary pacemakers. It is necessary to take discipline construction and professional construction as the guide, select a group of young and middle-aged teachers as reserve discipline leaders and professional leaders in a purposeful and planned way, strengthen training and exercise in practice, and establish a talent pool for future discipline leaders to stand out. It is necessary to gradually improve teachers' visiting and further education system, and encourage and select outstanding teachers to conduct high-level visiting and training in famous universities at home and abroad. It is necessary to focus on disciplinary pacemakers, strive to build a high-level innovation team, and promote the key disciplines construction. In addition, schools should increase investment, actively promote the "reserved professor cultivation" program, build a team of teachers with high professional titles and high quality, implement echelon development, and train high-level reserve talents.

The second is to establish and improve training path of young teachers. Young teachers are the backbone of a school and the new force of school development. Strengthening the cultivation and training of young teachers is an effective way to optimize the structure of teachers' academic qualifications, professional titles and disciplines, and it is also an important way for teachers to absorb new knowledge, broaden their horizons and enhance creativity. Training of young teachers can adopt the principle of combining expatriate exchange study with internal training in schools, namely, train with flexible and diverse forms.
The specific training forms are as follows: establish a perfect system of regular training, post-training and rotation training, and strengthen the pre-service, in-service and post-service training for young teachers, so that they can adapt to the environment as soon as possible, and be competent for work and improve their quality; Implement the tutorial system for young teachers and give full play to the role of old teachers in "passing on, helping and bringing"; promote the rapid growth of young teachers in the practice of teaching, scientific research and social service; strengthen training in practice and professional qualifications, guide young teachers to make scientific plans for their future careers, accelerate the transformation, and enable young teachers to find goals in curriculum, direction and growth; do well in construction of teaching and research sections and teaching teams to build a platform for the rapid and healthy growth of young teachers; send young teachers to well-known universities, research institutes, training institutions and enterprises to conduct domestic visits and overseas studies through the excellent teacher professional development project; encourage and support relevant teachers to apply for master's and doctoral students, and upgrade their academic qualifications.

To sum up, teacher education is a long-term systematic work. To effectively improve the quality of teachers and comprehensively improve their ability in teaching, scientific research and serving the society, we must make a good plan for the construction of teachers from an overall height of the school and formulate relevant regulations to organize teachers training; special funds must be equipped with to invest in teacher training. In the process of training, we should deal with the relationship between teachers' training and work. Training is the means, while improving teachers' professional level and cultivating talents are the ultimate goal. It is a must to avoid the embarrassing situation of "cultivation without usage" and "usage without cultivation". The former is a waste of education and training resources, while the latter will lead to the situation of "only milking cows, not grazing cows", which will eventually exhaust teachers' mental resources and be eliminated by the times.

\section{References}

[1] Zhan Xianming. "Double-qualified-type" Teacher Development Theory[M]. Hefei: Hefei University of Technology Press, 2010, 8:13-14.

[2] Chen Wei, Tian Yuan Jie. Research on the combination selection of "double-qualified-type" Teacher Cultivation Mode[J]. Chinese Vocational and Technical Education, 2012, (33): 65-68

[3] Zhang Wenjiao. Research on the Construction of Professional Teaching Staff in Application-oriented Undergraduate Colleges - Taking Ten Pilot Colleges in Hebei Province as Examples[D]. Hebei Normal University, 2019.

[4] Fu Bajun. On the Endogenous Model of Teaching Staff Construction in Application-oriented Universities[J]. Zhejiang Social Sciences, 2017 (06): 84-88 +158

[5] Liu Wei. Problems and Countermeasures of Teaching Staff Construction in Local Universities - Taking Applied talent cultivation Universities as an Example[J]. Chinese University Science and Technology, 2014 (09): $52-54$. 
[6] Pang Hefeng, Bo Yuming, Kong Jie. Current Situation and Strategy of Training "double-qualified-type" Teachers in Colleges and Universities[J]. Education and Occupation, 2015(12).

[7] Li Lihua. Investigation Report on the Construction of "double-qualified-type" Teachers in Higher Vocational College Universities - Taking Liaoning Province as an Example[J]. modern Education Administration, 2010 (10).

[8] Ji Li. Research on the Construction of "double-qualifiedtype" Teachers in Higher Vocational College Universities from the Perspective of Artisan Spirit[D]. Hebei Normal University of Science and Technology, 2019.

[9] Ye Rukun. On Training of Teachers of Teaching and Research Compound in Application-oriented Undergraduate Colleges[J]. Chinese Higher Education Evaluation, 2016, 27 (01). 31-34.

[10] R.Dean Gerdeman.The Role of Community College Training Tomorrow's School Teachers[J]. Community CollegeReview,2001,(Spring):62.

[11] Jian Cai Liang, Zhou Lijuan. On the Construction of Academic Echelon in Colleges and Universities[J]. People's Forum, 2011, (23).

\section{Author Profile}

Shijie Wang, President and Professor of Hefei Information University, Doctor of Montpellier University, France, mainly engaged in research on Applied Universities and higher education management. 